\title{
リン脂質を介したアポトーシス紐胞の貪食除去 Phospholipid-mediated Phagocytic Elimination of Apoptotic Cells
}

\author{
白土明子 \\ 金沢大学医薬保健研究域薬学系 \\ 生体防御応答学分野 \\ 干920-1192 石川県金沢市角間町 \\ 金沢大学自然科学研究科棟
}

\author{
中西義信 \\ 金沢大学医薬保健研究域薬学系 \\ 生体防御応答学分野 \\ 干920-1192 石川県金沢市角間町 \\ 金沢大学自然科学研究科棟
}

Yoshinobu NAKANISHI

Pharmaceutical and Health Science, College of Medical, Kanazawa University

Kakuma-machi, Kanazawa, Ishikawa

920-1192, JAPAN

論文要旨：私たちの一生を通じて, 多くの細胞が生理学的細胞死のアポトーシスを起こし, 速やかに貪食 を受けて生体から除去される。このアポトーシス細胞の貪食除去は，生体恒常性の維持に必要である。膜り ン脂質はこの現象に関与し，標的細胞が食細胞に認識される際の目印や食細胞中での食食誘導性情報伝達の 制御因子として働くことが知られる。本稿では，膜リン脂質に依存したアポトーシス細胞貪食反応の仕組み と意義とを解説する。

\begin{abstract}
Throughout the life of multi-cellular organisms, cells unnecessary or harmful to our body emerge. Such 'unwanted' cells need to be promptly and selectively removed for tissue homeostasis to be maintained. These cells are mostly induced to undergo physiologic cell death, i.e. apoptosis, and become susceptible to phagocytosis. Membrane phospholipids play important roles in the phagocytosis of apoptotic cells, serving as an earmark for apoptotic cells and a regulator of a signaling pathway for phagocytosis. In this article, we will describe the mechanisms and consequences of the phospholipidmediated phagocytosis of apoptotic cells.
\end{abstract}

Key words: phospholipid, phosphatidylserine, phagocytosis, apoptosis, innate immunity

\section{1 はじめに}

生物の最小単位は細胞であり，私達ヒトは，ひとつの 受精卵から発生した約 60 兆個の細胞から成りたってい る。そして，このように莫大な数の細胞は意味なく寄せ 集まっているのではなく，多様性，つまりさまざまな形 態と機能を持つ細胞が組織化しており，これらが物質と 情報をやり取りすることで，ひとつの生物としての恒常 性が保たれている。ヒトに限らずすべての多細胞生物で は，生を受けて成長し死に至るまでの一生を通じて，体 内ではかなりの数の不要細胞や有害細胞が頻繁に出現す る。このような細胞には，火傷や打撲のような不慮の死 とは異なるしくみと形態を持つ, “生理学的な細胞死”

連絡者：中西義信

E-mail : nakanaka@kenroku.kanazawa-u.ac.jp
が導かれる。この死は，1972 年にスコットランドの病 理学者 Kerr らがアポトーシス（apoptosis）と名付けた 特徵的な細胞形態を伴い，当時は電子顕微鏡像からそれ と判別されていた。その後に，モデル生物である線虫の 遺伝学的研究から細胞死を導く細胞内経路が発見され, 生理学的細胞死の機構は線虫からヒトを含む高等動物に 至るまで共通することがわかった。ところが，莫大な数 の細胞が日々死んでいるにもかかわらず，正常な組織で はごくわずかのアポトーシス細胞しか観察されない。こ れは，アポトーシス細胞が速やかにかつ選択的に排除さ れるためであり，排除機構の代表が領食（どんしょく） (phagocytosis) である。貪食とは細胞や大型構造物が 他の細胞内に丸ごと取り込まれる現象であり，食細胞 (phagocytes) と呼ばれる一群の細胞種がこれを担う。 アポトーシス細胞は，周囲の食細胞に荟食され，食細胞 
内のリソソームに運ばれてそこで分解除去される。この 反応は, 単なる不要物や有害物の除去という役割にとど まらず，領食により組織の形態や機能が維持され，また 貪食を起点とする新たな細胞応答が開始されることか ら, 細胞貪食は積極的な生体恒常性維持機構と位置づけ られる1,2)。

\section{2 アポトーシス細胞を貪食する食細胞}

哺乳類の食細胞の代表はマクロファージや好中球であ り，これらの細胞は主に血流に乗って体内を循環する。 これに対して，臓器に局在する食細胞も存在し，脳のミ クログリアや肝臓のクッパー細胞が挙げられる。これら の細胞は血球系細胞に分類されるが，この他にも嶺食活 性を有する細胞種が存在する。たとえば，血管平滑筋細 胞や精巣のセルトリ細胞，および網膜色素上皮細胞は, それぞれの組織で特有の機能を果たしながら，近くにア ポトーシス細胞が出現した時には食細胞としても働く。 また，昆虫にも専門の食細胞が複数種類存在する。一 方, 線虫には専門食細胞は存在せず，アポトーシス細胞 に隣接する細胞が必要時だけ食細胞として働く。このよ うに，生体内で生じたアポトーシス細胞の貪食は，それ ぞれの組織局在型の食細胞もしくは循環型の食細胞が担 当している。

\section{3 ホスファチジルセリンのアポトーシス細胞貪食目印 としての役割}

アポトーシス細胞貪食反応の解析の歴史は，役割を終 えた好中球や自己反応性胸腺細胞の排除機構の研究から 始まった。哺乳類の代表的食細胞であるマクロファージ がこれらの細胞を貪食することは古くから知られていた が，その認識機構はよくわかっていなかった。たとえ ば，マクロファージが生体内に侵入した微生物を貪食す る場合には, 自己由来細胞にはなく微生物だけが持つ分 子構造が識別される。しかし，標的細胞が自己細胞の場 合には，それが大多数の正常細胞の中から見つけだされ 選択的に貪食される必要がある。正常細胞との比較か ら，アポトーシス細胞では細胞表面および内部で構成成 分の構造や細胞内局在が変化するとわかってきた。これ より，アポトーシスに伴って新たに生じる細胞表面構造 が，食細胞による取り込みを誘導すると推測された (Fig. 1)。そして, アポトーシス細胞の表面に存在して 食細胞に認識される分子として最初に見いだされたの が，膜リン脂質のホスファチジルセリンである。ホス ファチジルセリンは通常は細胞膜の内側層に存在し，ア ポトーシスが起こった時に細胞表面に出現する (後述)。 アポトーシス細胞の貪食を導く標的側の因子は, 貪食目

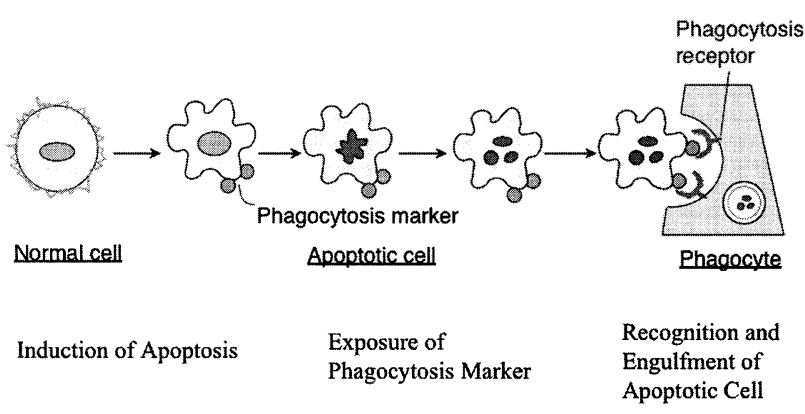

Fig. 1 Mechanism of the Recognition of Apoptotic Cells by Phagocytes.

During apoptosis, 'phagocytosis markers' appear at the cell surface. These markers are bound by phagocytosis receptors present at the surface of phagocytes, and the engulfment of apoptotic cells is induced.

印，あるいは eat-me signal と総称され，現在では，脂 質，タンパク質，糖鎖などさまざまな種類の分子がこの 役割を担うとわかっている。しかし，アポトーシス細胞 貪食の解析が始められた当時は，これらの実体は不明で あった。イングランドの Savil, 米国のFadok と Henson らの研究グループが中心となり，アポトーシス 時のマウス胸腺細胞やヒト好中球の表面では，膜リン脂 質の主要成分であるホスファチジルセリンやホスファチ ジルエタノールアミンの存在割合が顕著に高くなり，こ のうちホスファチジルセリンが食細胞に貪食を導くこと が示された ${ }^{3)}$ 。生きている細胞では，生体膜を構成する リン脂質群は脂質二重層の単分子膜間での存在割合が異 なっており，これは，フリッパーゼ，フロッパーゼ，ス クランブラーゼなどと名付けられた，膜に存在する複数 の脂質輸送体により維持される。たとえばヒトでは，多 くの組織細胞の細胞膜では，ホスファチジルセリンやホ スファチジルエタノールアミンの局在は細胞質に接する 側にかたよっており，食細胞が正常細胞の表面を見渡し た時には，これらのリン脂質は食細胞からは「見えな い」はずである。アポトーシスが誘導されると，リン脂 質の局在を司る輸送体群の活性が変化し，ホスファチジ ルセリンやホスファチジルエタノールアミンを脂質二重 膜の細胞質側の単分子膜から反対側の単分子膜に速やか に移行させる。その結果，これらのリン脂質が細胞表面 に「出現」して食細胞により感知される（Fig. 2)。現在 では，ホスファチジルセリンは多くの哺乳類組織でアポ トーシス細胞の貪食目印として働くことが報告されてお $\eta^{4)}$, さらに, 線虫やショウジョウバエでもホスファチ ジルセリンを介する貪食機構の存在が解析と議論の途上 にある ${ }^{5)}$ 。アポトーシス細胞で働くリン脂質輸送体の候 補として，複数の分子がこれまでに提唱されているが, その実体と活性調節の仕組みはまだ十分に理解されては 


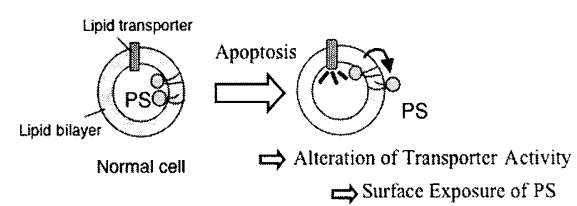

Fig. 2 Mechanism of the Externalization of Phosphatidylserine in Apoptotic Cells

Phosphatidylserine is normally restricted to the inner leaflet of the plasma membrane bilayers. Upon the induction of apoptosis, the activity of lipid transporters that regulate the distribution of phospholipids is altered. As a consequence, phosphatidylserine becomes distributed in the outer leaflet and is thus exposed to the cell surface.

いない。また, 食細胞への効率よい貪食の誘導要因とし て，ホスファチジルセリンが膜の特定領域に高密度で存 在したり，アシル基の切断や酸化または還元反応を受け て構造変化することの必要性が提案されており, ホ久 ファチジルセリンの存在様式だけでなく構造の変化が食 細胞とアポトーシス細胞との親和性を増大させて取り込 みを充進させている可能性がある。一方, ホスファチジ ルセリン以外の膜リン脂質も, アポトーシス時に構造や 局在の変化を起こし領食反応を調節する。たとえば，ア ポトーシス細胞膜ではリン脂質分解酵素活性が変化し て, ホスファチジルコリンからリゾホスファチジルコリ ンが作られて細胞外に放出され，これは食細胞の集積や 活性化を導く生理活性脂質として働く。ちなみに, 細胞 膜リン脂質の再配分は, アポトーシス時に限定的な現象 ではなく, 血液凝固を導く血小板の活性化時や細胞分裂 時など，さまざまな細胞応答の場面で生じると知られ， 局在の変化した脂質が情報分子や足場分子となって細胞 応答を導く。また，ホスファチジルセリンの細胞表層へ の出現は, すべてのアポトーシス細胞に生じるわけでは なく,アポトーシスの進行に必須ではないと理解されて いる。

\section{4 アポトーシス細胞貪食を誘導する食細胞の情報経路}

アポトーシス細胞が食細胞に認識されると, 多くの場 合には, 食細胞の一部が足を伸ばすように突起を形成 し，アポトーシス細胞はこれに包み込まれるように食細 胞内に取り达まれて食食胞を形成する。仮足と呼ばれる 細胞膜の突起構造は細胞骨格のひとつであるアクチン㵶 維に富み, アポトーシス細胞のような大型標的を取り込 む際には食細胞の細胞膜は大きくたわみ，これにはアク チン繊維の構造変化を伴う ${ }^{6)}$ 。アクチンは球状のタンパ ク質であり，細胞内の情報を受けて重合と脱重合が調節 され, 細胞骨格の繊維状構造を形成する (Fig. 3)。細胞 内のアクチン骨格再編成は, 低分子量 G タンパク質の
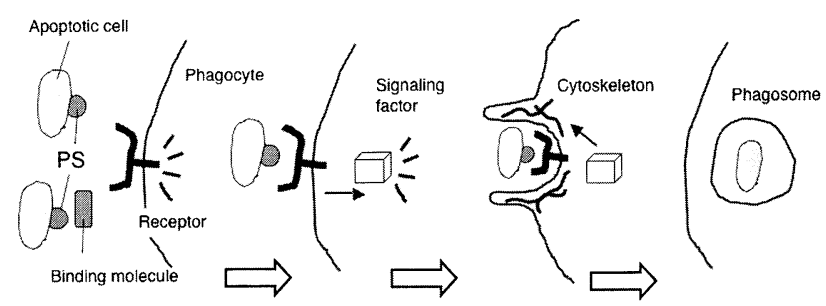

$$
\begin{array}{llll}
\text { Receptor } & \text { Signaling } & \begin{array}{l}
\text { Cytoskeleton } \\
\text { Rearrangement }
\end{array} & \text { Engulfment } \\
\text { Activation } & &
\end{array}
$$

Fig. 3 Mechanism of the Engulfment of Apoptotic Cells by Phagocytes.

The binding of phosphatidylserine, either directly or indirectly with the aid of bridging molecules, activates phagocytosis receptors. Activated receptors in turn induce signaling pathways leading to the restructuring of actin filaments for engulfment.

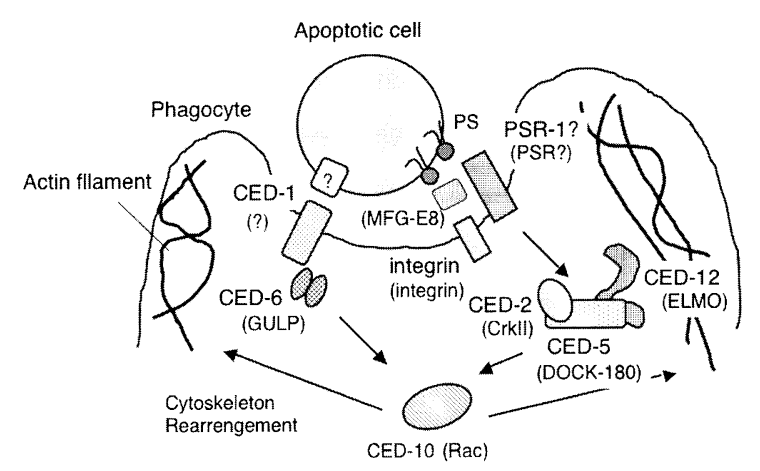

Fig. 4 Pathways for the Phagocytosis of Apoptotic Cells by Phagocytes of Caenorhabditis elegans.

The names and orders of signal mediators contained in two distinct pathways for phagocytosis are shown. The parentheses indicate the names of mammalian counterparts of Caenorhabditis elegans proteins.

Rho ファミリーにより制御され，この中でも Rac, Cdc 42 , およびRhoの 3 種類の活性の時期と場所を限定した厳 密な調節が，貪食を含め細胞形態変化の多くを司ってい る。一方, アポトーシス細胞貪食を導く食細胞内経路に ついては, 線虫について遺伝学を用いた解析が哺乳類に 先行して解析されてきた7.8)。線虫では, アポトーシス細 胞会食の細胞内経路は 2 つ存在し, 一方は CED $-1 \rightarrow$ CED-6 $\rightarrow$ CED-10, 他方は CED-2 $\rightarrow$ CED-5 $\rightarrow$ CED-12 $\rightarrow \mathrm{CED}-10$ と呼ばれる分子群で構成されている。このう ち, CED-1 は膜一回貫通型の受容体夕ンパク質であり, CED-2 と CED-6 は細胞内のアダプター分子, CED-10 は低分子量 $\mathrm{G}$ タンパク質, そして CED-5 と CED-12 は CED-10 の活性調節因子として働く。その後, これらの 分子にはショウジョウバエや哺乳類にホモログ（相同分 子）が存在するとわかり, 領食経路の解析は線虫の知見 を利用することで哺乳類でも進んできた。また， CED-10 は哺乳類 Rac のホモログであることから，2つ の経路は Rac の活性変化に集約して標的細胞の取り込み 
が導かれると考えられる $\left(\right.$ Fig. 4) ${ }^{6}$ 。 $。$ この分野の研究初 期には, 線虫で見いだされた分子機構がどれほど高等生 物に当てはまるのかを疑問視する向きもあったが，現在 では, 細胞へのアポトーシス誘導およびその嶺食機構は ともに, 生物進化の過程で種を越えて保存されると理解 された。

\section{5 ホスファチジルセリンを介する貪食誘導性受容体と 食細胞内経路}

ホスファチジルセリンが䕘食目印とわかり, 食細胞上 にはこれを感知する受容体が存在すると考えられた。こ れまでに, 多数のホスファチジルセリン受容体候補が提 唱されているが, これらは二通りに大別でき, 標的細胞 との結合親和性を高める ‘tethering receptor' と, 食 細胞による取り込みを導く ‘signaling receptor' とが存 在する。そして，ホスファチジルセリンの認識は, 可溶 性のホスファチジルセリン結合因子が両細胞の橋渡しと なる場合と，ホスファチジルセリンが食細胞の膜受容体 に直接認識される場合の二通りが知られている。また, 貪食誘導性のホスファチジルセリン受容体は複数提唱さ れているが, リガンド結合様式から食細胞内で低分子量 G タンパク質経路活性化に至るまでの機構が示されたも のはまだわずかである。可溶性のホスファチジルセリン 結合分子とその受容体を介する代表例は, 可溶性因子 milk fat globule epidermal growth factor 8 (MFG-E 8) である ${ }^{9)}$ 。ホスファチジルセリンと結合した MFG-E 8 は食細胞の膜受容体インテグリンとも結合して両細胞の 橋渡しとなり，インテグリンが哺乳類の食細胞内で CED-2, CED-5, CED-12 のホモログを通じて低分子量 G タンパク質を介する標的細胞の貪食を起こす。また免疫 細胞に多く局在する膜受容体 Tyro 3 ファミリーに属す る Tyro 3, Axl, Mer は，ホスファチジルセリンと結合し た液性因子 growth arrest specific gene 6 (Gas6) を認 識し, 同様の仕組みで苓食を導く ${ }^{4)}$ 。一方, ホスファチ ジルセリンと直接結合する膜受容体の例として，クラス B スカベンジャー受容体タイプI（SR-BI） ${ }^{10,11)}$, brainspecific angiogenesis inhibitor 1 (BAI 1) ${ }^{12)}$, stabilin-2 ${ }^{13)}$, T-cell immunoglobulin- and mucin-domaincontaining molecule 4 (Tim 4) ${ }^{14)}$ などが報告されてい る。このうち, stabilin-2 と SR-BI はともに, その細胞 内領域でアダプター分子 GULP (CED-6 の哺乳類ホモ ログ）と結合してアポトーシス細胞の取り达みを導き， BAI 1 は ELMO（CED-12 の哺乳類ホモログ）の上流で 働く。また, 線虫では食食誘導性受容体の CED-1 はホ スファチジルセリンをリガンドとして認識すると考えら れているが，CED-1のショウジョウバエホモログであ
る Draper は，ホスファチジルセリン以外の分子を認識 してアポトーシス細胞貪食を導くと考えられている ${ }^{5)}$ 。 これより，食細胞の細胞内経路は，目印分子ではなく食 細胞受容体に規定されるように思われる。実際に，ひと つの食細胞にはホスファチジルセリン受容体群を含む複 数種類の領食受容体が存在することが知られ，これらの 発現様式は組織の種類により，あるいは炎症物質などの 外的要因で変化する。また，ホスファチジルセリンを認 識する領食受容体の中にはこれ以外のリガンドとも結合 して取り込みを導く分子も存在する。そして，貪食受容 体からの細胞内経路の標的は，取り込みを導く細胞骨格 だけではなく，酵素活性変動を介した細胞内代謝や食細 胞内の転写反応の変化をもたらす。たとえば，領食時に は食細胞から炎症調節物質や抗微生物性物質が産生さ れ，組織の恒常性維持に働く。これらのことょり，領食 目印と領食受容体との組み合わせや，領食誘導の細胞内 情報経路は，領食時の組織内外の環境に応じて適切に選 択されると考えられる。

\section{6 貪食された細胞の処理とアポトーシス細胞貪食の生 理学的意義}

領食されたアポトーシス細胞は，まず貪食胞と呼ばれ る膜小胞内に隔離される。これがさらにエンドソームや リソソームと融合してファゴリソソームとなり，その内 部でアポトーシス細胞の分解が行われる。ファゴリソ ソームが形成される一連の過程で，膜に存在するプロト ンチャネルの働きにより領食胞の内部は酸性化し，酸性 条件に至適水素イオン濃度指数を持つリソソームの各種 加水分解酵素の活性が発揮される。また，貪食胞の膜に NADPH オキシターゼ複合体が会合して活性酸素を産生 し，内部のラジカル濃度が高まる（Fig. 5 $)^{2)}$ 。アポトー シス細胞はこれらの酵素やラジカルの攻撃により破壊さ れ，アポトーシス細胞由来の変性物質や有害物が分解排 除される。また，微生物感染によりアポトーシスを起こ した細胞も食細胞により領食されることが知られてお り，この場合にはアポトーシス細胞内の微生物も同時に 排除される (後述)。

多くのアポトーシス研究者は先ずアポトーシスを導く 分子機構の解明に着手し，そのためか，食食について は，後処理として単に不要物や有害物を生体からの排除 するための消極的な細胞応答と考えられた時期もあっ た。現在では，アポトーシス細胞の貪食は，物理的また 機能的に生体恒常性維持に働く積極的な反応であるとわ かってきた。たとえば，手足の指では指の間の細胞がア ポトーシスを起こし貪食により排除されることによりそ の形が作られ，胸腺では自己反応性のリンパ球はアポ 


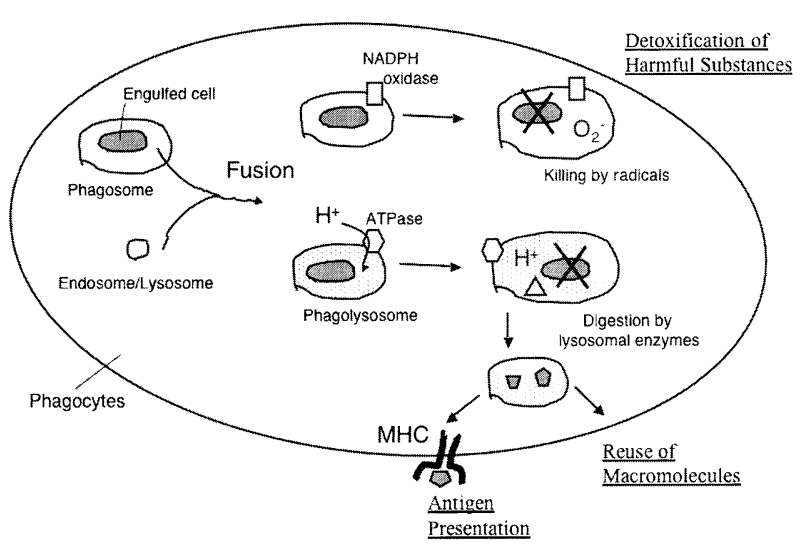

Fig. 5 The Fate of Engulfed Apoptotic Cells in Phagocytes. Apoptotic cells are internalized as phagosomes that are ultimately fused with endosomes/lysosomes giving rise to phagolysosomes. Thanks to ATPase, phagolysosomes are acidified so that lysosomal enzymes become functional to digest engulfed materials. On the other hand, NADPH oxidases of phagolysosomes produce radicals such as superoxide that kill engulfed cells. In some cases, the digestion of engulfed materials is partial, and cleaved materials are reused by other cells or transferred to the cell surface for antigen presentation by immune cells.

トーシスを起こして領食され適切に働く免疫細胞群が作 られる。また，役割を終え古くなった細胞の貪食は細胞 の置き換えの例といえる。変態を行う動物では，領食に より成虫の体を作る空間が生まれ，また，分解された幼 虫細胞由来の高分子は成虫の体を作る材料として再利用 される。一方，食細胞が抗原提示能を有する場合には， 部分分解されたアポトーシス細胞の破片は食細胞表層に 移動して，その情報がリンパ球に伝達されることで免疫 機能が活性化する。受容体側からの研究では, 上述する Tyro 3 ファミリー受容体を介する頜食不全が個体で生じ ると, 免疫機能に異常が生じて自己免疫疾患などの原因 となることが提唱されている。また， MFG-E 8 と integrin を介する領食反応は, 網膜色素上皮細胞の更新, 脳 での損傷神経細胞の除去, 役割を終えた乳腺細胞の廃宩 など，さまざまな組織の機能維持に寄与している。

筆者らは, 哺乳類の精子形成にはアポトーシス精子形 成細胞の領食が必要であることを報告してきた。精巣内 で分化を始めた精子形成細胞は，その大多数が精子への 分化途中でアポトーシスを起こして死妨。これらの細胞 は，セルトリ細胞と呼ばれる精巣内の体細胞に領食排除 される。セルトリ細胞は上皮系由来で精巣精細管内に分 布する組織局在型の食細胞であり, 哺育細胞として精子 形成細胞に分化因子や生存因子を与えている。セルトリ 練胞は上述した受容体の SR-BI を細胞表層に持ち，こ れがアポトーシス精子形成細胞上のホスファチジルセリ
ンと直接結合して標的の取り込みを行う ${ }^{11)}$ 。さらに, 生 きたマウスやラットの精巣内でホスファチジルセリンを 介する領食を抑制すると, 組織中には食食されずに残っ たアポトーシス細胞数が増大し，また，作られる精子数 が激減する。これらのことより,この反応は精子形成の 進行に必要であることが判明した ${ }^{10)}$ 。これは，アポトー シス細胞領食の分子機構と生理的意義との雨方が証明さ れた例といえる。

\section{7 ホスファチジルセリンに調節される微生物および微 生物感染細胞の貪食排除}

ホスファチジルセリンを介する貪食反応は，感染微生 物の排除にも働く。筆者らは, インフルエンザウイルス の感染により細胞がアポトーシスを起こすことを初めて 報告し,このような細胞の領食機構を解析してきた。イ ンフルエンザウイルス感染細胞では，アポトーシスに 伴って細胞表層にホスファチジルセリンが出現し，これ を目印分子として感染細胞はマクロファージや好中球に 領食される。また, ウイルス由来の膜タンパク質のノイ ラミニターゼ（neuraminidase, NA）は感染細胞の食食 を調節する。NA は, 感染細胞からウイルス粒子が出芽 して放出される際に, 宿主細胞膜からウイルス粒子を切 り離す糖鎖切断酵素であり，臨床現場では NA の阻害剂 が抗ウイルス薬として処方されている（リレンザや夕ミ フル）。インフルエンザウイルス感染細胞の表面には NAが存在しており，マクロファージが感染細胞と接触 するとマクロファージ細胞膜の糖鎖もこの酵素による切 断を受ける。そして，新たに細胞表面に出現した糖鎖 が，マクロファージによるウイルス感染細胞の食食を調 節する。すなわち，インフルエンザウイルス感染細胞 は, アポトーシス細胞に共通性の高い目印分子ホスファ チジルセリンと, ウイルス感染特異的に生じる糖鎖構造

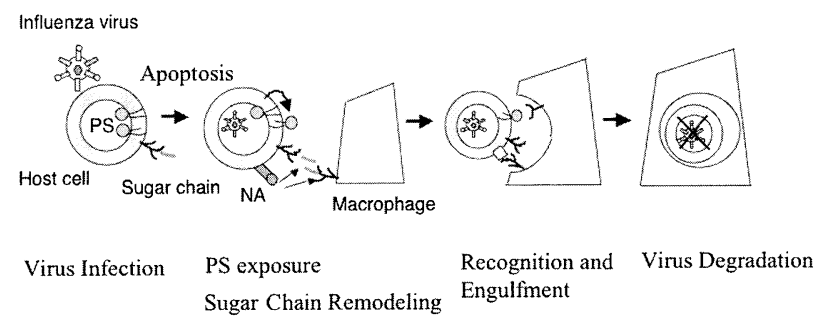

Fig. 6 Phagocytic Elimination of Influenza Virus-infected Cells.

The infection of influenza virus causes apoptosis in host cells, which accompanies the exposure of phosphatidylserine. These cells then undergo phosphatidylserine-mediated phagocytosis by macrophages or neutrophils. Influenza virus together with host cells is degraded in phagocytes, and this event helps to minimize the development of influenza. 


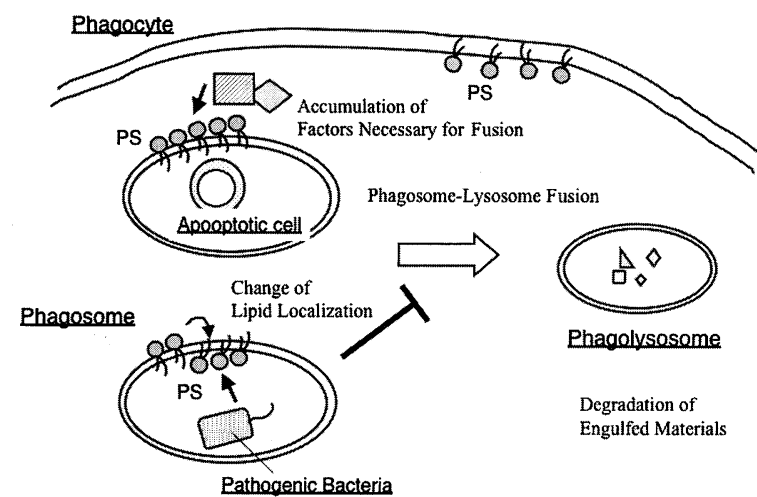

Fig. 7 Bacterial Strategy for the Survival in Phagocytes after Engulfment.

Engulfed bacteria alter the distribution of phospholipids in the membrane of phagosomes to inhibit their fusion with endosomes/lysosomes.

との両者により，その貪食が調節される (Fig. 6)。さら に, ウイルス感染細胞の食食により, ウイルス増殖が完 全に抑制される。上述する領食反応を選択的に抑制した マウスにインフルエンザウイルスを経鼻感染させると, 肺組織でのウイルスの増殖と炎症が充進し，またこのよ

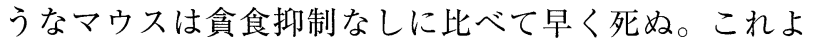
り，インフルエンザウイルス感染細胞の食食は，ウイル スを感染細胞もろとも破壊する感染防御反応であると考 えられる ${ }^{15,16)}$ 。

一方で, 微生物が, ホスファチジルセリンを介する領 食反応を利用して，宿主の免疫を回避する例も知られ る。原虫の中には, 宿主体内に侵入すると原虫自身の表 層にホスファチジルセリンを出現する種類が存在する。 そのような原虫は食細胞に効率よく取り込まれ, 食細胞 内で生き延びて増殖し, 宿主に高い致死性をもたら す ${ }^{17)}$ 。また, ある種の病原性細菌は, 宿主の食細胞に貪 食され領食胞に捉えられると, 食食胞膜を構成する脂質 局在を変化させる。貪食胞のホスファチジルセリンは細 胞質に接する側に多く存在し, ここに貪食胞結合因子群 が集積して, 食食胞のファゴリソソームへの成熟を調節 する。しかし，脂質の局在が変化すると，領食胞はリソ ソームと融合できず，取り达まれた細菌はラジカルやリ ソソーム酵素の攻撃を逃れて増殖する (Fig. 7) ${ }^{18)}$ 。この ような現象は, 宿主食細胞の貪食機構を逆手に取った微 生物の生存戦略といえるだろう。

\section{8 むすび}

アポトーシス細胞では，さまざまな種類の膜リン脂質 について, 分子内構造および膜における集積状態が変化 するとともに, 脂質二重層内での局在, そして細胞内外 での存在場所が大きく変化する。このように変化した脂
質は，近隣の食細胞にアポトーシス細胞に向けた集積を 促し，食細胞の活性を変化させ，そして，食細胞による アポトーシス細胞の認識と取り込みを導く。本稿では紹 介しなかったが，ホスファチジルイノシトールとその関 連物質は細胞膜の内側層, すなわち細胞質に接する側に 主に存在しており，これらはさまざまな細胞応答を調節 する細胞内情報経路構成因子の代表である。この経路 は，アポトーシス細胞の取り込みや，取り込まれた標的 の食細胞内での処理でも詳細な調節を行っている。ま た，微生物の中には，宿主食細胞のこれらの仕組みを巧 みに利用して, 免疫から回避して感染と増殖を謀る種類 も存在する。ここまで述べてきたように，アポトーシス 細胞の貪食は，免疫記憶に必要な遺伝子再編成を必要と せず，線虫からヒトまでその仕組みの大枠は保存されて いる。また，ホスファチジルセリンに限らず䕘食目印分 子群は，アポトーシス時に新たに合成された分子ではな く, 細胞がもともと持っている分子がその構造や局在を 変化させて働く点が共通している。アポトーシス細胞の 領食反応は, 自然免疫応答による生体恒常性維持機構1,22 として重要な位置を占める。今後，ホスファチジルセリ ンを始めとするリン脂質の貪食反応素過程での働きのさ らなる解明が，本反応の全体像の理解に必要である。

\section{文献}

1) CA. Janeway, Jr., Proc Natl Acad Sci USA, 98, 7461-8 (2001).

2) Y. Nakanishi, Yakugaku Zasshi, 126, 1207-12 (2006).

3) Y. Nakanishi, P.M. Henson \& A. Shiratsuchi, (book chapter) Target Pattern Recognition in Innate Immunity, chapter 11 (U. Kishore ed.), Landes Bioscience, Austin (2009).

4) Y. Wu, N. Tibrewal N, \& R.B. Birge, Trends Cell Biol, 16, 189-97 (2006).

5) Y. Nakanishi, \& A. Shiratsuchi, Invertebrate Survival Journal, 3, 89-96 (2006).

6) Y. Nakanishi \& A. Shiratsuchi, Seikagaku, 78, 1429-37 (2003).

7) P.W. Reddien \& H.R. Horvitz, Annu. Rev. Cell Dev. Biol., 20, 193-221 (2004).

8) Z. Zhou \& X. Yu, Trends Cell Biol., 18, 474-85 (2008).

9) R. Hanayama, M. Tanaka, K. Miwa, A. Shinohara, A. Iwamatsu \& S. Nagata, Nature, 417, 182-7 (2002).

10) Y. Nakanishi \& A. Shiratsuchi, Biol. Pharm. Bull., 27, 13-6 (2003).

11) A. Shiratsuchi \& Y. Nakankshi, Seikagaku, 73, 187-90 (2001).

12) D. Park, A.C. Tosello-Trampont, M.R. Elliott, M. Lu, L.B. Haney, Z. Ma, A.L. Klibanov, J.W. Mandell \& K.S. Ravichandran, Nature, 450, 430-4 (2007).

13) S.Y. Park, S.Y. Kim, M.Y. Jung, D.J. Bae \& I.S. Kim, $M o l$. Cell Biol., 28, 5288-98 (2008). 
14) M. Miyanishi, K. Tada, M. Koike, Y. Uchiyama, T. Kitamura \& S. Nagata, Nature, 450, 435-9 (2007).

15) A. Shiratsuchi \& Y. Nakanishi, Yakugaku Zasshi, 126, 1245-51 (2006).

16) Y. Hashimoto, T. Moki, T. Takizawa, A. Shiratsuchi \& Y. Nakanishi, J. Immunol., 178, 2448-57 (2007).

17) L. Wanderley, L.H. Pinto da Silva, P. Deolindo, L. Soong,
V.M. Borges, D.B. Prates, A.P. de Souza, A. Barral, J.M. Balanco, M.T. do Nascimento, E.M. Saraiva \& M.A. Barcinski, PLoS ONE, 4, e 5733 (2009).

18) T. Yeung, H. Bryan, J-F. Dubuisson, G.D. Fairn, B. Chiu, R. Inman, A. Kapus, M. Swanson \& S. Grinstein, J. Cell Biol., 185, 917-28 (2009). 